\title{
Abnormal Adrenal Responsiveness and Angiotensin II Dependency in High Renin Essential Hypertension
}

\author{
Robert G. Dluhy, Sam Z. Bavli, Frank K. Leung, Harold S. Solomon, \\ Thomas J. Moore, Norman K. Hollenberg, and Gordon H. Williams, \\ Endocrinology-Hypertension Unit, Peter Bent Brigham Hospital and \\ Department of Medicine, Harvard Medical School, Boston, Massachusetts \\ 02115
}

A B S T RACT Adrenal responsiveness to angiotensin II (AII) and the diastolic blood pressure responses to saralasin were studied in 19 patients with high renin essential hypertension (HREH) on a 10-meq $\mathrm{Na}^{+} / 100$ meq $\mathrm{K}^{+}$diet. The increment in plasma renin activity (PRA) between supine and upright positions was used as an estimate of the acute stimulation of the adrenal gland by endogenous AII; the normal increment in plasma aldosterone divided by the increment in PRA was $>3.8$. 7 of 19 had abnormal upright posture responses with significantly greater mean PRA increments $(24 \pm 6 \mathrm{ng} / \mathrm{ml}$ per $\mathrm{h})$ and significantly smaller plasma aldosterone increments $47 \pm 16 \mathrm{ng} / \mathrm{dl})(P<0.036)$ compared to the increments observed in HREH patients with normal adrenal responsiveness (PRA $=15 \pm 1 \mathrm{ng} / \mathrm{ml}$ per $\mathrm{h}$; plasma aldosterone $=87 \pm 17 \mathrm{ng} / \mathrm{dl})$. When AII was infused at doses of $0.1-3 \mathrm{ng} / \mathrm{kg}$ per min, only patients with normal posture responses had normal plasma aldosterone increments; plasma aldosterone levels failed to significantly increase even at the highest infusion rate in the patients with the abnormal upright posture responses. The AII competitive inhibitor, saralasin $(0.3-30 \mu \mathrm{g} / \mathrm{kg}$ per min) was then infused to study the occurrence of angiotensinogenic hypertension in both HREH subgroups. The mean decline in diastolic blood pressure to saralasin in the subnormal adrenal responsive patients $(-15 \pm 3 \mathrm{~mm} \mathrm{Hg})$ was significantly greater than in the normal adrenal responsive group $(-3 \pm 2 \mathrm{~mm}$ $\mathrm{Hg})(P<0.02)$.

It is concluded that patients with HREH are not a homogeneous population; approximately one-third have AII-dependent hypertension. In these patients, the mechanism responsible for the elevated renin and blood pressure could be a compensatory increase

Address reprint requests to Dr. Dluhy.

Received for publication 15 January 1979 and in revised form 25 June 1979. secondary to decreased adrenal responsiveness to AII. In the remainder, the high PRA levels have little, if any, causal role in the pathogenesis of the hypertension but could reflect a marker of other pathophysiologic processes.

\section{INTRODUCTION}

Approximately $15 \%$ of patients with essential hypertension have plasma renin levels elevated above the normal range. It has been suggested that plasma renin plays an important role in the pathogenesis and/or the maintenance of the blood pressure elevation in all patients with high renin activity. For example, Case et al. (1) reported depressor responses to saralasin in most patients with high renin values, but their study group included patients with essential hypertension, renal artery stenosis, and malignant hypertension. On the other hand, Streeten et al. (2) reported that only one-half the patients with high renin levels showed a fall in blood pressure during saralasin infusion, concluding that not all high renin patients had angiotensinogenic hypertension. Others have suggested that plasma renin is a marker of other pathophysiologic processes and not necessarily a pathogenic mechanism in its own right (3). In these studies, high plasma renin levels have been viewed as resulting from sympathetic overactivity which produces both the hypertension and the concomitant release of renin.

Thus, the prevalence of angiotensinogenic hypertension in patients with high renin essential hypertension (HREH) ${ }^{1}$ has been obscured by the diverse patient populations in previous studies. Moreover, if the high renin levels reflect diverse pathophysiologic

\footnotetext{
'Abbreviations used in this paper: AII, angiotensin II; HREH, high renin essential hypertension; PA, plasma aldosterone; PRA, plasma renin activity; RAS, renal artery stenosis.
} 
mechanisms, it would be expected that the elevated renin and angiotensin II levels might produce or sustain the elevated arterial blood pressure only in a subset of patients with HREH. Therefore, the present study was performed to assess the role of angiotensin in the pathophysiology of hypertension in patients with HREH using the angiotensin II competitive inhibitor, saralasin. The renin-angiotensin-aldosterone interrelationships were also studied in saralasin responders and nonresponders since we have previously postulated that elevated renin levels and an elevated arterial blood pressure could result from subnormal aldosterone responsiveness if the vascular response to angiotensin II was normal (4). In addition vascular and adrenal responses were compared to patients with renal artery stenosis (RAS) where it is generally agreed that the hypertension is angiotensin mediated.

\section{METHODS}

11 normotensive controls (six males, five females), 20 patients with HREH, and 10 patients with RAS were studied at the Clinical Center of the Peter Bent Brigham Hospital. The protocol was approved by the Human Subjects Committee of the Peter Bent Brigham Hospital and written informed consent was obtained from all patients and normal subjects. The age range of the hypertensive subjects was $19-68 \mathrm{yr}$ (mean, $42 \mathrm{yr}$ ) and that of the normal controls was 20-29 $\mathrm{yr}$ (mean, $28 \mathrm{yr}$ ). Responses of HREH and RAS patients were also compared to normal renin essential hypertension patients who have, in part, been reported (4). Patients were classified as HREH if their sodium-restricted, upright plasma renin activity (PRA) exceeded the upper levels reported for normotensive controls in our laboratory (15 ng) $\mathrm{ml}$ per $\mathrm{h}$ ) (5). The essential hypertensive patients reported in the present study were not on an ad lib or normal sodium intake. However, a study of 25 hypertensive patients in our laboratory has shown a highly significant correlation between upright PRA on an ad lib compared to a 10-meq sodium diet $(r=0.62, P<0.01)$, suggesting that there is internal agreement between both methods of classification. Hypertensive patients had diastolic blood pressures over $90 \mathrm{~mm} \mathrm{Hg}$ on at least three different occasions before study. Creatinine clearance, urinalysis, and serum and urine electrolytes were normal as were 24 -h urinary vanillyl-mandelic acid, metanephrines, catecholamines, 17 hydroxysteroids, and 17 ketosteroids. In essential hypertensive patients, renal vascular disease was excluded by rapid sequence intravenous pyelography, radioisotopic renogram, and when indicated, renal angiography and bilateral renal vein renin determinations. RAS was documented by an abnormal arteriogram, lateralizing renal vein renins with contralateral suppression, and cure or significant improvement (blood pressure $<150 / 95$ on no medications) after surgery. All medications were discontinued at least $2 \mathrm{wk}$ before admission. The patients were fed an isocaloric $10 \mathrm{meq}$ sodium/100 meq potassium diet. 24-h urinary collections were analyzed daily for sodium, potassium, and creatinine.

Upright posture study. Plasma samples were obtained for the determination of PRA, plasma aldosterone (PA), cortisol, sodium, and potassium, in the supine and after 120 and 150 min of upright posture. Patients with essential hypertension were allocated to the HREH group according to their upright
PRA. The range of PRA in normal subjects in our laboratory under identical conditions is $2.4-15 \mathrm{ng} / \mathrm{ml}$ per $\mathrm{h}$ (5). Release of endogenous renin and generation of angiotensin II are increased by upright posture. Therefore, the increment in PRA between supine and upright positions ( $\triangle P R A$ ) can be used as an estimate of the degree of acute stimulation of the adrenal gland by angiotensin II. Thus, the ratio $\triangle P A: \triangle P R A$ reflects the response of plasma aldosterone relative to changes in plasma renin. When plasma PA is expressed in $\mathrm{ng} / \mathrm{dl}$, normal values for this ratio are $\geq 3.8$ (4).

Angiotensin II infusion. After an overnight fast, with the subject in the supine position while in balance on a 10-meq sodium diet, 14 HREH patients and 6 normotensive controls, and 4 patients with RAS were infused with angiotensin II (AII). Control blood samples were obtained and a graded infusion of AII (Hypertensin, CIBA-Geigy Corp., Pharmaceuticals Div., Summit, N. J.) was begun with a Harvard infusion pump (Harvard Apparatus Co., Inc., Millis, Mass.) at rates of $0.1,0.3,1.0$, and $3.0 \mathrm{ng} / \mathrm{kg}$ per min as described $(4,6)$. Each dose was infused for $30 \mathrm{~min}$ and blood samples were obtained before and at the end of each dose level for determination of AII, cortisol, sodium, and potassium, and PA. Blood pressure was monitored (Arteriosonde, Roche Diagnostic's Div., Hoffman-La Roche Inc., Nutley, N. J.) at 2-min intervals for a $30-\mathrm{min}$ control period and throughout the AII infusion.

Saralasin infusion. Saralasin infusions were performed in 19 patients with HREH and in all the normal subjects and patients with RAS supine in balance on a 10-meq sodium intake. Saralasin (1-sar, 8-ala angiotensin; Norwich-Eaton Pharmaceuticals, Norwich, N. Y.) was administered intravenously in graded doses beginning at either 30 or $100 \mathrm{ng} / \mathrm{kg}$ per min with a Harvard infusion pump. The dose was increased in semi-log increments to $0.3,1.0 .3 .0,10.0$, and 30 $\mu \mathrm{g} / \mathrm{kg}$ per min (each dose given for $6 \mathrm{~min}$ ) unless a rise in arterial blood pressure or a fall in diastolic pressure of greater than $15 \mathrm{~mm} \mathrm{Hg}$ occurred. An Arteriosonde was used for blood pressure measurements at 1- or 2-min intervals.

Laboratory procedures. All samples were collected on ice and centrifuged immediately and the plasma separated and frozen until time for assay. Samples for PRA and AII determinations were anticoagulated with EDTA; samples for cortisol and aldosterone were anticoagulated with heparin. Serum and urine sodium and potassium concentrations were measured by flame photometry with lithium as an internal standard. PA, PRA, and AII were measured by radioimmunoassay as described $(7,8)$. Values for PRA and AII were reported in reference to the World Health Organization standards 71-328 and 70-302, respectively.

Statistical methods. The results are expressed as mean $\pm \mathrm{SE}$. Differences between groups were tested by Student's $t$ test, Fisher exact test, or by the Wilcoxon rank sum test where appropriate (9). All infusions were analyzed by two-way analysis of variance; $P$ values for $t$ tests were obtained from Dunnett's tables (10). The logarithmic transformation was used for statistical evaluation when appropriate. The threshold dose for a significant response to AII was defined as that dose that produced a blood pressure or PA increment significantly different from control. The null hypothesis was rejected for $P<0.05$.

\section{RESULTS}

Characteristics of the hypertensive groups. The general clinical characteristics of the hypertensive patients are summarized in Table I. Patients with HREH were younger than those with RAS $(P<0.05)$. 
TABLE I

Characteristics of Hypertensive Patients

\begin{tabular}{lcc}
\hline & HREH & RAS \\
\hline Number & 19 & 10 \\
Number female & 7 & 5 \\
Number black & 3 & 0 \\
Age, $y r$ & $36 \pm 3.1^{*}$ & $50 \pm 5.1$ \\
Duration of hypertension & $4.4 \pm 0.9$ & $12.3 \pm 3.8$ \\
Weight loss, admission to low $\mathrm{Na}^{+}$ & & \\
$\quad$ balance, $k g$ & $1.8 \pm 0.3$ & $0.7 \pm 0.3$ \\
Serum sodium, meq/liter & $136 \pm 0.8 \ddagger$ & $140 \pm 0.8$ \\
Serum potassium, meq/liter & $4.2 \pm 0.1$ & $4.2 \pm 0.1$ \\
Serum creatinine, $m g / d l$ & $1.0 \pm 0.04$ & $1.1 \pm 0.1$ \\
Low salt urine Na ${ }^{+}$, meq $/ 24 h$ & $5 \pm 1$ & $9 \pm 2$ \\
Low salt urine $\mathrm{K}^{+}$, meq $/ 24 h$ & $78 \pm 3$ & $90 \pm 11$ \\
Admission systolic BP, $m m \mathrm{Hg}$ & $146 \pm 4 \ddagger$ & $176 \pm 10$ \\
Admission diastolic BP, $m m \mathrm{Hg}$ & $96 \pm 2$ & $101 \pm 4$ \\
Low salt PRA (upright), $n g / m l / h$ & $30 \pm 3 \ddagger$ & $14 \pm 2$ \\
\hline
\end{tabular}

Results are expressed as mean \pm SEM. BP, blood pressure.

* Significantly different from RAS $(P<0.05)$.

$\ddagger$ Significantly different from RAS $(P<0.01)$.

Duration of hypertension tended to be greater in RAS (12.3 yr) than in HREH (4.4 yr) but the difference was not significant. Admission systolic blood pressure in HREH patients was significantly lower than in RAS patients $(P<0.01)$; admission diastolic blood pressures tended to be lower in HREH patients but the difference was not statistically significant. In the patients with $\mathrm{HREH}$, serum sodium concentration $(136 \pm 0.8$ [SE] meq/liter) was significantly lower $(P<0.01)$ than in patients with RAS $(140 \pm 0.8$ meq/ liter). Urinary sodium excretion was also lower in HREH $(5.2 \pm 1 \mathrm{meq} / 24 \mathrm{~h})$ than in RAS $(9 \pm 2 \mathrm{meq} / 24 \mathrm{~h})$ but the differences were not significant. There were no significant differences between HREH or RAS patients in racial distribution, serum creatinine, serum potassium, 24-h urine potassium excretion, or amount of weight loss with salt restriction. Sodium restricted upright PRA was significantly lower in RAS (14 $\pm 2 \mathrm{ng} /$ $\mathrm{ml}$ per $\mathrm{h})$ than HREH patients $(30 \pm 3 \mathrm{ng} / \mathrm{ml}$ per $\mathrm{h})$ $(P<0.01)$.

Upright posture study. Adrenal sensitivity to endogenous AII was estimated in HREH patients by the ratio of the increment in PA divided by the increment in PRA when the subject changed from the supine to the upright position. In 11 normotensive controls reported previously, the mean supine and upright plasma renin activities were $2.7 \pm 0.3$ and $9.2 \pm 0.8$ $\mathrm{ng} / \mathrm{ml}$ per $\mathrm{h}$ and supine and upright PA were $24 \pm 5$ and $78 \pm 14 \mathrm{ng} / \mathrm{dl}(4) .7$ of $19 \mathrm{HREH}$ patients $(37 \%)$ were abnormal when viewed by the previously reported normal criteria (ratio $\geq 3.8$ ). In a previous report we found that 12 of 64 patients with normal renin essential hypertension (19\%) were abnormal by these same criteria (4). Thus, there were no significant differences between normal renin essential hypertensive and HREH patients with regard to the fraction of abnormal responses to upright posture. On the other hand, of 10 patients with RAS, 9 had normal $\triangle \mathrm{PA}: \triangle \mathrm{PRA}$ ratios.

Response to saralasin. The mean decline in diastolic blood pressure in the 19 patients with HREH $-7 \pm 2(\mathrm{SE}) \mathrm{mm} \mathrm{Hg}$ was significantly less than that seen in patients with RAS $(-16 \pm 4 \mathrm{~mm} \mathrm{Hg})(P<0.05)$. No patients with RAS but 4 of 19 patients with HREH had an agonistic rise in diastolic blood pressure after the infusion of saralasin. Under identical conditions of sodium restriction, the mean decline in diastolic blood pressure in normotensive controls was $-5 \pm 0.5$ (SE) $\mathrm{mm} \mathrm{Hg}(\mathrm{SD}=2.0)$, establishing a lower limit of normal for a decrement in diastolic blood pressure of $-9 \mathrm{~mm}$ $\mathrm{Hg}$ in that setting (11). 7 of 19 patients with HREH and 8 of 10 patients with RAS had decrements in diastolic blood pressure of $10 \mathrm{~mm} \mathrm{Hg}$ or greater.

AII and saralasin infusions in HREH subgroups and RAS patients. As a group the HREH patients and normal subjects had identical AII threshold sensitivities for both significant blood pressure and aldosterone increments (1 $\mathrm{ng} / \mathrm{kg}$ per min). However, if categorized according to their $\triangle \mathrm{PA}: \triangle \mathrm{PRA}$ responses, differences were apparent (Tables II and III). In patients with HREH and an abnormal (low $\triangle \mathrm{PA}: \triangle \mathrm{PRA}$ ) ratio, vascular sensitivity to infused AII was normal (threshold dose $1.0 \mathrm{ng} \mathrm{AII} / \mathrm{kg}$ per min), while the aldosterone

\section{TABLE II}

Threshold Dose for Significant Increments* in Blood Pressure and PA Levels and the Maximal Mean Increments in Aldosterone after Graded Infusions of AII (0.1 -3.0 ng/kg per min) in Patients with HREH with Normal and Abnormal Adrenal Responsiveness to AII $\ddagger$

\begin{tabular}{lcr}
\hline & $\begin{array}{c}\text { Normal } \\
\Delta \text { PA: } \Delta \text { PRA }\end{array}$ & $\begin{array}{c}\text { Low } \\
\Delta \text { PA: } \mathrm{PRA}\end{array}$ \\
\hline $\begin{array}{l}\text { Threshold dose AII for significant } \\
\text { increment, } n \mathrm{~g} / \mathrm{kg} / \mathrm{min}\end{array}$ & & \\
$\quad$ Mean blood pressure & $>3.0$ & 1.0 \\
$\quad$ Plasma aldosterone & 1.0 & $>3.0$ \\
Mean PA increment above control & & \\
$\quad \begin{array}{l}\text { at AII infusion rate of } 1 \mathrm{ng} / \mathrm{kg} / \\
\text { min (mean } \pm \text { SEM), ng/dl }\end{array}$ & $29 \pm 10 \S$ & $4.5 \pm 2.5$
\end{tabular}

* See Methods for definition.

$\$$ The $\triangle$ PA: $\triangle$ PRA ratio in patients with HREH is an estimate of adrenal sensitivity to endogenous AII, defined as the increment in PA ( $\triangle P A)$ divided by the increment in PRA ( $\triangle P R A$ ) during a sodium-restricted upright posture study. A normal $\triangle \mathrm{PA}: \triangle \mathrm{PRA}$ ratio $\geq 3.8$.

$\S$ Significantly different from low $\triangle \mathrm{PA}: \triangle \mathrm{PRA} \quad(P<0.016$, Fisher exact test). 
TABLE III

Comparison of Patients with HREH and Normal or Abnormal Adrenal Responsiveness to AII

\begin{tabular}{|c|c|c|}
\hline & $\begin{array}{c}\text { Normal } \\
\text { دPA: } \triangle P R A\end{array}$ & $\begin{array}{c}\text { Low } \\
\triangle \mathrm{PA}: \triangle \mathrm{PRA}\end{array}$ \\
\hline Number & 12 & 7 \\
\hline Mean ratio & $7.3 \pm 1.1$ & $2.3 \pm 0.3$ \\
\hline Upright salt-restricted PRA, $n g / m l / h$ & $25 \pm 2$ & $38 \pm 7$ \\
\hline $\begin{array}{l}\text { Upright salt-restricted plasma aldosterone, } \\
n g / d l\end{array}$ & $124 \pm 20$ & $94 \pm 30$ \\
\hline Mean PRA increments, $n g / m l / h$ & $15 \pm 1^{*}$ & $24 \pm 6$ \\
\hline $\begin{array}{l}\text { Mean plasma aldosterone increments, } n g / d l \\
\text { Admission BP } m m H g\end{array}$ & $87 \pm 17^{*}$ & $47 \pm 16$ \\
\hline Systolic & $152 \pm 6$ & $14.3 \pm 7$ \\
\hline Diastolic & $95 \pm 3$ & $103 \pm 5$ \\
\hline Control BP for saralasin infusion, $m \mathrm{~m} \mathrm{Hg}$ & & \\
\hline Systolic & $132 \pm 5$ & $123 \pm 6$ \\
\hline Diastolic & $78 \pm 8$ & $81 \pm 3$ \\
\hline $\begin{array}{l}\text { Saralasin infusion-decrement diastolic BP, } \\
\quad m m \mathrm{Hg}\end{array}$ & $-3 \pm 2 \ddagger$ & $-15 \pm 3$ \\
\hline Number male & $5 / 12$ & $6 / 7$ \\
\hline Age & $41.7 \pm 3.8$ & $30.4 \pm 3.5$ \\
\hline Black & $1 / 12$ & $0 / 7$ \\
\hline Serum $\mathrm{K}^{+}$, meq/liter & $4.3 \pm 0.1$ & $4.1 \pm 0.2$ \\
\hline Serum $\mathrm{Na}^{+}$, meq/liter & $1.36 \pm 0.8$ & $136 \pm 1.1$ \\
\hline Low salt urine $\mathrm{Na}^{+}$, meq/24h & $5 \pm 1$ & $1 \pm 0.3$ \\
\hline Low salt urine $\mathrm{K}^{+}$, meq $/ 24 h$ & $74 \pm 5$ & $84 \pm 7$ \\
\hline Weight loss, admission $\rightarrow$ low $\mathrm{Na}^{+}$balance, $k g$ & $-1.5 \pm 0.3$ & $-2.0 \pm 0.5$ \\
\hline
\end{tabular}

Results are expressed as mean \pm SEM. BP, blood pressure.

* Significantly different from low $\triangle \mathrm{PA}: \triangle \mathrm{PRA}(P<0.036$, Fisher exact test $)$.

$\$$ Significantly different from low $\triangle \mathrm{PA}: \triangle \mathrm{PRA}(P<0.02)$.

levels did not significantly increase even at the highest infusion rate (Table II) $(n=6)$. Only a small number of subjects with RAS $(n=4)$ were infused with AII because of the magnitude of the blood pressure elevations recorded. In these patients with RAS, vascular sensitivity to AII was also normal (threshold dose, $1.0 \mathrm{ng} / \mathrm{kg}$ per $\mathrm{min}$ ). The rise in PA levels was normal in three of four subjects; the mean PA increment was $11 \pm 5 \mathrm{ng} / \mathrm{dl}$ at $1 \mathrm{ng} / \mathrm{kg}$ per min compared to an increment of $6 \mathrm{ng} / \mathrm{dl}$ or greater in normotensive controls. In HREH patients with normal $\triangle P A: \triangle P R A$ postural responses, vascular reactivity to infused AII was greatly decreased, while the PA response to AII was normal (Table II) $(n=8)$.

The recumbent systolic and diastolic blood pressure levels in balance on a 10-meg sodium diet on the day of the saralasin infusion had declined into the normotensive range and were not significantly different between both HREH subgroups (Table III).

The mean \pm SEM blood pressure response to the infusion of saralasin in the normal $(n=12)$ and abnormal $(n=7) \quad \triangle \mathrm{PA}: \triangle \mathrm{PRA}$ patients with HREH are presented in Fig. 1. A significantly greater number of abnormal $\triangle$ PA: $\triangle$ PRA patients (five of seven) had depressor responses to saralasin (diastolic blood pressure decline of $10 \mathrm{~mm} \mathrm{Hg}$ or greater $)(P<0.028$, Wilcoxon rank sum test) compared to HREH patients with normal $\triangle P A: \triangle P R A$ ratios (2 of 12 ). The mean decline in diastolic blood pressure in the abnormal ratio patients $(-15 \pm 3 \mathrm{~mm} \mathrm{Hg})$ was identical to that recorded in patients with RAS and was significantly greater than the mean decline in diastolic blood pressure in the normal ratio patients $(-3 \pm 2 \mathrm{~mm} \mathrm{Hg}$ ) $(P<0.02)$. No patient with an abnormal ratio had an agonistic blood pressure response after the infusion of saralasin, but an agonistic response was seen in 3 of 12 normal $\triangle P A: \triangle P R A$ HREH patients. Patients with abnormal and normal $\triangle \mathrm{PA}: \triangle \mathrm{PRA}$ ratios did not have significant differences between sodium-restricted upright plasma renin levels ( $38 \pm 7$ vs. $25 \pm 2 \mathrm{ng} / \mathrm{ml}$ per $\mathrm{h}$, respectively) or plasma aldosterone levels $(94 \pm 30 \mathrm{vs}$. $124 \pm 20 \mathrm{ng} / \mathrm{dl}$, respectively). However, the mean PRA increments were significantly greater $(24 \pm 6$ vs. $15 \pm 1 \mathrm{ng} / \mathrm{ml}$ per $\mathrm{h}$ ) and the mean PA increments were significantly smaller $(47 \pm 16$ vs. $87 \pm 17 \quad \mathrm{ng} / \mathrm{dl}) \quad(P$ $<0.036$, Fisher exact test) in the abnormal compared to the normal $\triangle \mathrm{PA}: \triangle \mathrm{PRA}$ ratio HREH patients (Table III). A summation of the various responses of the 19 


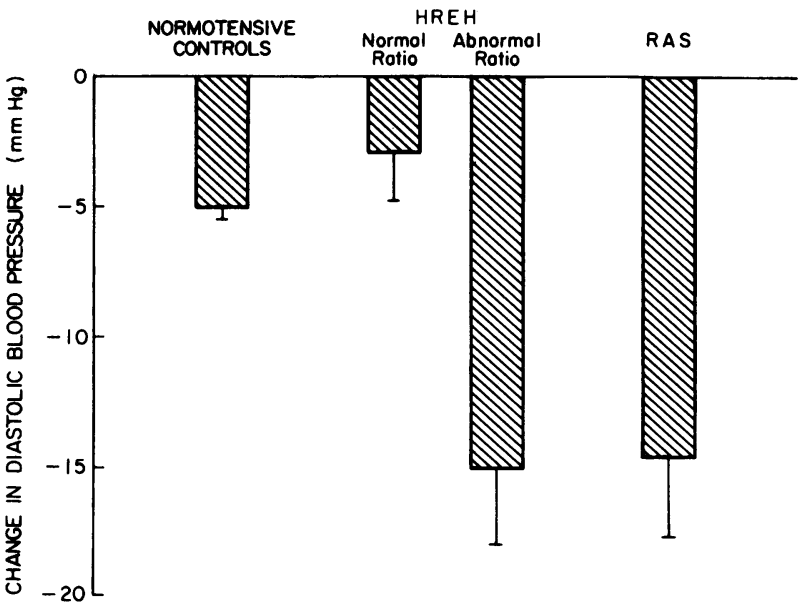

Figure 1 Mean \pm SEM decrements in diastolic blood pressure after the infusion of saralasin in graded doses in normotensive controls, patients with HREH and RAS. HREH patients with normal and abnormal adrenal responsiveness to AII (see Table II) had sodium-restricted, upright plasma renin levels exceeding $15 \mathrm{ng} / \mathrm{ml}$ per $\mathrm{h}$.

patients with HREH to the various manipulations is presented in Table IV.

\section{DISCUSSION}

The present study documents that patients with HREH are not a homogeneous population. Under the conditions of sodium restriction, approximately one-third of patients with HREH were found to have responses consistent with angiotensinogenic hypertension based on diastolic blood pressure depressor responses to saralasin ( $10 \mathrm{~mm} \mathrm{Hg}$ or greater) that exceeded those previously reported in a normotensive control population studied under identical conditions (11). These HREH patients also had subnormal adrenal responsiveness to AII. One interpretation of these findings is that the high renin and AII levels in these patients reflect a compensatory attempt to close the renin-AII-aldosterone volume feedback loop. In the remaining HREH patients, the high levels of PRA may represent a marker of other pathophysiologic processes with the elevated blood pressure being sustained by nonangiotensinogenic mechanisms.

Altered adrenal responsiveness to AII has been documented in patients with essential hypertension. Kisch et al. (6) and Wisgerhof and Brown (12) have reported that patients with normal or low plasma renin levels on high sodium intakes have increased adrenal responsiveness to AII. Decreased adrenal responsiveness has also been reported in patients with normal renin essential hypertension on a sodium-restricted intake (4). In the present study, $37 \%$ ( 7 of 19 ) patients with HREH studied on a sodium-restricted intake had decreased adrenal responsiveness to AII as determined by the ratio of the increment of PA to the increment in plasma renin activity in the upright position. The lower absolute upright PA levels in the HREH patients with subnormal adrenal responsiveness also suggests that their decreased adrenal responsiveness was not secondary to near maximal secretion in the basal state (Table III). Altered adrenal responsiveness in 14 of these 19 subjects was directly confirmed by infusing AII with the low $\triangle \mathrm{PA}: \triangle \mathrm{PRA}$ group responding subnormally both in terms of threshold dose and absolute aldosterone increments (Table II).

In the presence of high circulating plasma renin levels, patients with subnormal adrenal responsiveness maintained normal vascular reactivity to infused AII. Thus, the threshold dose of AII ( $1 \mathrm{ng} / \mathrm{kg}$ per min) required to achieve a significant increment in blood pressure in these patients was the same as in normotensive controls. Although a limited number (4) of AII infusions were performed in patients with RAS, vascular reactivity also appeared to be normal. The normal vascular sensitivity to exogenous AII in the four patients with renovascular hypertension might be unexpected, because these patients with elevated levels of PRA would be anticipated to be less sensitive to the pressor effects of AII. On the other hand, several studies have shown no differences between RAS and normotensive subjects with regard to the pressor doses of AII necessary to achieve a $20 \mathrm{~mm} \mathrm{Hg}$ rise in diastolic blood pres-

TABLE IV

Summary of Studies in 19 HREH Patients

\begin{tabular}{lcc}
\hline & \multicolumn{2}{c}{ Upright posture studies* } \\
\cline { 2 - 3 } & Normal & Abnormal \\
\hline $\begin{array}{l}\text { Number } \\
\text { Saralasin depressor responsiveness }(>10 \mathrm{~mm} \mathrm{Hg} \text { fall } \\
\text { in diastolic pressure) }\end{array}$ & 12 & 7 \\
$\begin{array}{l}\text { Blood pressure response to infused AII } \\
\text { PA response to infused AII }\end{array}$ & $2 / 12$ & $5 / 7$ \\
\end{tabular}

* $\triangle$ PA: $\triangle$ PRA normally $\geq 3.8$ (Table II). 
sure (13) or a rise in diastolic blood pressure after the infusion of AII at a dose of $10 \mathrm{ng} / \mathrm{kg}$ per min (14). However, the small number of infusions performed in the present study and the differences in study conditions (the present study carried out under sodium restriction with almost all previous studies performed on ad lib sodium intakes) do not allow a definitive assessment of AII pressor responsiveness in RAS patients. Since the blood pressure response to infused AII in patients with RAS and HREH patients with subnormal adrenal responsiveness appears to be normal in the setting of elevated circulating renin levels, the net effect could lead to an elevated blood pressure. In both these hypertensive patient groups the response to saralasin was also uniformly depressor.

On the other hand, HREH patients with normal $\triangle \mathrm{PA}: \triangle \mathrm{PRA}$ ratios had blunted pressor responses to infused AII. This is the expected result in patients with high PRA levels because the prolonged presence of high serum AII concentrations has been shown to induce a relative vascular resistance to AII. For example, the pressor response to AII is blunted in malignant hypertension (13), in cirrhosis $(13,15)$, in sodiumrestricted normal subjects (16), and in women taking oral contraceptives (17), conditions that are all associated with elevated renin and AII levels. Thus, because the HREH patients with normal $\triangle$ PA: $\triangle$ PRA ratios had renin levels higher than sodium-restricted normal subjects, a reduced vascular sensitivity to infused AII would be anticipated. One explanation for the higher renin levels in these patients with normal $\triangle P A: \triangle P R A$ ratios could be a greater degree of sodium depletion. There was no objective evidence to support this speculation. For example, there were no significant differences in weight loss after low sodium balance was achieved between the normal and abnormal ratio groups (Table III) and previous reported normal subjects (5). On the other hand, this blunted pressor response to infused AII in $\cong 60 \%$ of our patients with HREH may account for the tendency for blood pressure to be only mildly elevated in most reported series of patients with HREH despite the elevated plasma renin levels $(5,18,19)$.

It is unlikely that the HREH subgroup with subnormal adrenal responsiveness and angiotensinogenic hypertension contained patients with occult RAS. Hypertensive intravenous pyelograms and renograms were normal in these seven HREH subjects and renal arteriography was normal in the three patients where it was performed. Moreover, although vascular reactivity to infused AII was similar in the RAS and the AII-dependent HREH subgroup, adrenal responsiveness was strikingly different. All patients with the low $\triangle \mathrm{PA}$ : $\triangle$ PRA ratio by definition had subnormal aldosterone responses to upright posture, whereas 9 of 10 patients with documented RAS had normal postural aldosterone responses. Therefore, in the HREH patients where the hypertension appeared to be AII dependent, radiographic adrenal sensitivity studies failed to indicate that these patients had occult RAS. The patients with RAS also serve as an important comparison group for HREH patients with subnormal adrenal responsiveness. Although both groups appear to have angiotensinmediated hypertension, normal adrenal responsiveness in patients with RAS appears to exclude factors such as age, elevated blood pressure, and AII levels per se as producing the altered adrenal responsiveness in HREH patients with the low $\triangle \mathrm{PA}$ : $\mathrm{PRA}$ ratios.

The mechanism of the altered adrenal response to AII in one-third of HREH patients is unclear. There were no significant differences in sodium balance, urinary sodium excretion, urinary potassium excretion, or serum potassium levels in the two subgroups. We have previously postulated that altered adrenal sensitivity is best accounted for by a change in the interaction of AII with its adrenal receptor (20). This alteration could produce hypertension by necessitating greater activation of the renin-angiotensin system to close the volume-renin-aldosterone feedback loop, thereby resulting in greater constrictor activity.

From the present study, the mechanism(s) responsible for the increased renin levels in the HREH patients with normal vascular responsiveness to saralasin is unknown. Compared to saralasin-responsive HREH patients, the normal vascular responsiveness in these patients with normal adrenal responsiveness cannot be accounted for by their lower supine renin values because their PRA levels ( $10 \pm 2 \mathrm{ng} / \mathrm{ml}$ per $\mathrm{h}$ ) were still significantly greater than in normals and similar to that recorded in the RAS patients $(10 \pm 2 \mathrm{ng} / \mathrm{ml}$ per $\mathrm{h}$ ) who had depressor responses.

In summary, patients with HREH do not appear to be a homogeneous population. Some HREH patients have AII-dependent hypertension; in these patients, the mechanism responsible for the elevated renin and blood pressure could be a compensatory increase secondary to decreased adrenal responsiveness to AII. In the remainder, the high PRA levels have little, if any, causal role in the pathogenesis of the hypertension and the mechanism responsible for the increased renin is unknown. Finally, these results may provide an explanation for the observation of Dustan et al. (21) that in HREH, unlike in RAS, a positive correlation of blood pressure with PRA cannot be demonstrated.

\section{ACKNOWLEDGMENTS}

This work was supported by grants from the National Institutes of Health (HL 14944, HL 11668, GM 18674, HL 18882, HL 5436, and HL 05144). The studies were performed at a Clinical Research Center that is supported by a grant from the Division of Research Resources of the National Institutes of Health (5-M01-RR00888). 


\section{REFERENCES}

1. Case, D. B., J. M. Wallace, H. J. Kein, J. E. Sealey, and J. H. Laragh. 1976. Usefulness and limitations of saralasin, a partial competitive agonist of angiotensin II, for evaluation of the renin and sodium factors in hypertensive patients. Am. J. Med. 60: 825-836.

2. Streeten, D. H. G., G. H. Anderson, and T. G. Dalakos, 1976. Angiotensin blockade: its clinical significance. Am. J. Med. 60: 817-824.

3. Esler, M., A. Zweifler, O. Randall, S. Julius, and V. DeQuattro. 1978. The determinants of plasma renin activity in essential hypertension. Ann. Intern. Med. 88: $746-752$.

4. Moore, T. J., G. H. Williams, R. G. Dluhy, S. Z. Bavli, T. Himathongkam, and M. Greenfield. 1977. Altered renin-angiotensin-aldosterone relationships in normal renin essential hypertension. Circ. Res. 41: 167-171.

5. Tuck, M. L., G. H. Williams, J. P. Cain, J. M. Sullivan, and R. G. Dluhy. 1973. Relation of age, diastolic pressure and known duration of hypertension to presence of low renin essential hypertension.Am.J. Cardiol. 32: 637-642.

6. Kisch, E. S., R. G. Dluhy, and G. H. Williams. 1976. Enhanced aldosterone response to angiotensin II in human hypertension. Circ. Res. 38: 502-505.

7. Underwood, R. H., and G. H. Williams. 1972. The simultaneous measurements of aldosterone, cortisol and corticosterone in human peripheral plasma by displacement analysis. J. Lab. Clin. Med. 79: 848-862.

8. Emanuel, R. L., J. P. Cain, and G. H. Williams. 1973. Double antibody radioimmunoassay of renin activity and angiotensin II in human peripheral plasma. J. Lab. Clin. Med. 81: 632-640.

9. Armitage, P. 1971. Statistical Methods in Medical Research. John Wiley \& sons, Inc., New York.

10. Dunnett, C. W. 1964. New tables for multiple comparisons with a control. Biometrics. 10: 482-491.

11. Hollenberg, N. K., G. H. Williams, D. F. Adams, T. J. Moore, C. Brown, L. J. Borucki, F. K. Leung, S. Z. Bavli, H. S. Solomon, D. Passon, and R. G. Dluhy. 1979. Re- sponse to saralasin and angiotensin's role in essential and renal hypertension. Medicine. 58: 115-127.

12. Wisgerhof, M., and R. D. Brown. 1978. Increased adrenal sensitivity to angiotensin II in low-renin essential hypertension. J. Clin. Invest. 61: 1456-1462.

13. Kaplan, N. M., and J. G. Silah. 1964. The effect of angiotensin II on the blood pressure in humans with hypertensive disease. J. Clin. Invest. 43: 659-669.

14. Yamamoto, Y. 1975. Effect of pressor agents on blood pressure, plasma renin activity and plasma aldosterone concentration in essential hypertension. Jpn. Heart J. 16: 404-420.

15. Ames, R. P., A. L. Borkowski, A. M. Sicinski, and J. H. Laragh. 1965. Prolonged infusions of angiotensin II and norepinephrine and blood pressure, electrolyte balance, and aldosterone and cortisol secretion in normal man and in cirrhosis with ascites. J. Clin. Invest. 44: 1171-1186.

16. Hollenberg, N. K., W. R. Chenitz, D. F. Adams, and G. H Williams. 1974. Reciprocal influence of salt intake on adrenal glomerulosa and renal vascular responses to angiotensin II in normal man. J. Clin. Invest. 54: 34-42.

17. Hollenberg, N. K., G. H. Williams, B. Burger, W. Chenitz, I. Hooshmand, and D. F. Adams. 1976. Renal blood flow and its response to AII: an interaction between oral contraceptive agents, sodium intake and the renin-angiotensin system in healthy young women. Circ. Res. 38: 35-40.

18. Esler, M., S. Julius, A. Zweifler, O. Randall, E. Harburg, H. Gardiner, and V. DeQuattro. 1977. Mild high-renin essential hypertension: neurogenic human hypertension? N. Engl. J. Med. 296: 405-411.

19. Frohlich, E. D., V. J. Kozul, R. C. Tarazi, and H. P. Dustan. 1970. Physiological comparison of labile and essential hypertension. Circ. Res. 26(Suppl. 1): 55-69.

20. Williams, G. H., N. K. Hollenberg, T. J. Moore, S. Swartz, and R. G. Dluhy. 1979. The adrenal receptor for AII is altered in essential hypertension. J. Clin. Invest. 63: 419-427.

21. Dustan, H. P., R. C. Tarazi, and E. D. Frohlich. 1970. Functional correlates of plasma renin activity in hypertensive patients. Circulation. 41: 555-567. 